JOURNAL OF SECURITY AND SUSTAINABILITY ISSUES

ISSN 2029-7017 print/ISSN 2029-7025 online

2021 Volume 11

https://doi.org/10.47459/jssi.2021.11.1

\title{
INTERPRETATION AND PERCEPTION OF MILITARY POWER BY APPLYING PERSPECTIVES OF NEOCLASSICAL REALISM AND MILITARY STUDIES
}

\author{
Agniete Zotkeviciute Baneviciene \\ General Jonas Zemaitis Military Academy of Lithuania, Silo st. 5A, Lithuania \\ E-mails: agniete.zotkeviciute@lka.lt
}

Received 15 July 2020; accepted 10 December 2020; published 30 March 2021

\begin{abstract}
Although the issues of military studies are increasingly analysed in the framework of political science, the representatives of international relations and military studies use different ways of interpreting military power - one of the key aspects of military studies. With the intention of expanding the possibilities of applying theories of international relations to military studies, this article aims to show the need for a synthesis of theoretical insights into neoclassical realism and military studies for scientific interpretation and research of the military power structure. The inducement of inter-paradigmatic debates by revealing and comparing military power explanation methods reflects a theoretical attempt to expand the possibilities for the application of international relations theories on warfare studies. Although the application of neoclassical realism theory to the explanation of military power is not new, this study explores broader possibilities of the application of this theory. The study substantiates the influence of non-material resources and unit-level variables on the structure of military power while making the assumption that neoclassical realism creates conditions to reveal the process of military power conversion but not the content of military power.
\end{abstract}

Keywords: Military power, Security studies, Political science, Neoclassical realism, Force employment.

Reference to this paper should be made as follows: Zotkeviciute Baneviciene, A. 2021. Interpretation and perception of military power by applying perspectives of neoclassical realism and military studies. Journal of Security and Sustainability Issues, 11, 5-28. https://doi.org/10.47459/jssi.2021.11.1

JEL Classifications: F50, H56

Additional disciplines: political science, military studies

\section{Introduction}

While defining resources constituting military power, representatives of realism and neorealism bring to light the significance of material elements - weaponry, manpower, a part of the state budget allotted to defence and modern military technologies (Raitasalo 2015: 98-99). Among the most frequently used quantitative military power measurement methods is the Composite Indicator of National Capability created for the Correlates of War Project (See Singer 1972; Singer 1982). the Global Firepower Index, the Military Expenditure Database, the Global Militarization Index. Despite the prevailing quantitative methods of measuring military power in the interpretation of international relations, a significant number of sceptics note that the methods of measuring military power based on material resources are limited in terms of application (See Gordon, Trainor 1995; Woodward 1991). For example, the methodology of war correlates is criticised for being suitable exclusively for the analysis of conventional conflicts. After the Cold War, most conflicts are asymmetric in nature, therefore, resource-based methods of estimating military power are no longer sufficient for military power analysis (Gentry 2011, 6).

Given the limited explanatory power of methodologies for estimating military power based on material re- 
sources, research has been initiated to integrate intangible resources into the structure of military power (See Biddle 2006; Goldman, Eliason 2003; Alison, Zelikow 1999). Research concerning fighter skills has provided evidence of the importance of training in increasing the army's efficiency and military power (See Brooks, Stanley 2007: 12), as well as the importance of military morality, leadership (See Dupuy 1985). For example, leaders plan to use material resources in military organisations, thus directly affecting the military power (See Shimshoni 1990/1992).

Contextual factors such as democracy, values, level of development and quality of society also influence military power. Dan Reiter and Allan Stam studied the influence of regimes on military power and found that democratic states are winning more battles than undemocratic regimes. Interpreting this trend as the impact of democratic political institutions on leadership and the initiative of militants on the battlefield (See Reiter 2002). Michael C. Desh also highlighted democracy as an important leveraged for the effectiveness of military power (See Desch 2002). Barry R. Posen highlighted the influence of nationalism on military power: states deliberately promote nationalism in order to improve their military capabilities (See Posen 1993: 80-124). In their study, Risa A. Brooks and Elizabeth A. Stanley noted the influence of societies, cultures, political structures, and the global environment on military power and its effectiveness (Brooks, Stanley 2007). A study by Stephen Biddle and Robert Zirkle reveals how differences between the society and army relationships in Iraq and North Vietnam affected army relative power in mastering sophisticated military technology (See Biddle, Zirkle 2008). In addition, Biddle points out, along with Stephen Long, that the cultural peculiarities of Muslims and Buddhists influence the fighting ability on the battlefield against Western opponents (Biddle, Long 2004). Biddle and Long hypothesise that better-educated soldiers may be more inclined to learn, better able to master sophisticated weapons, and be able to perform tactical manoeuvres on the battlefield, and, by confirming the hypothesis, conclude that developed countries with high levels secondary education and higher education exceed less educated enemies on the battlefield (Biddle, Zirkle 2008). Stephen Rosen reveals the effects of class and caste stratification, highlighting the influence of cultural and social factors on military power (See Rosen 1996). Ruth Benedict equates the Japan's cruel, suicidal defence during World War II with Japanese concepts of honour and shame (See Benedict 1946), meanwhile, according to Kenneth Michael Pollack, Arab cultural characteristics explain poor tactical initiatives by Arab state's armies, lack of intelligence, poor tactical manoeuvres and systematic display of individual courage leading to limited effectiveness of military power (Pollack 1996: 579).

John Garnett points out that military power cannot be defined without taking the ratio of power into account. Military power is based on political relations between potential adversaries and is thus tailored to the specific situation. Thus, even extremely high material capacity may not be appropriate or adaptable to a specific situation (Garnett 1987: 84). It can be argued that the relative nature of military power is increasingly emphasised in the scientific literature, with an accent on the impact of the security environment (See Dorman 2002: 6-8; Biddle 2006; Farell, Terriff 2002).

The influence of the security environment on military power has long been recognised in classical warfare and security studies, emphasising that military power depends largely on intangible resources - military strategies, doctrines, and tactics (See Rotte, Schmidt 2003; Arreguin-Toft 2005; Stam 1996; Mearsheimer 1983; Gow 2006; McMurry 1989, 117; Lyall, Wilson 2009) or, as Biddle puts it, the ways of force employment. Qualitative research of John Mearsheimer, Barry Posen, Jack Snyder, Elizabeth Kier and others highlight the importance of (military) strategies for military power (Mearsheimer 1983; Posen 1984; Snyder 1984; Kier 1997). Scott Bennett and Allan Stam in their study reveal the interaction between the elements of military power - military strategy and success in wars (Bennett, Stam 1996, cited in Grauer 2012: 87). Joseph Samuel Nye note that "But whether the capacity that those resources imply can actually be converted into preferred outcomes will depend upon the contexts and the country's skill in converting resources into strategies that will produce preferred outcomes." (Nye 2011: 10). Thus, regardless of the different terminology used by scholars, whether it is the force employment or power conversion strategies, different scientific sources emphasise that tangible resources of military power are inseparable from their uses - intangible resources such as strategies, military doctrines, etc. 
Research methodology. Despite individual studies substantiating the importance of intangible resources in the structure of military power, the structure of military power itself is hardly analysed in the literature of international relations. The analysis of military power through the theory of neoclassical realism scientifically justifies how states transform their tangible and intangible resources into forming military power at strategic, operational and tactical levels. An essential feature of this theory is that it provides theoretical assumptions for exploring how systemic variables (security environment) influence the structure of military power through intervening variables (perceptions of military doctrine formers) (Lobell et al 2009: 293). Although the application of the theory of neoclassical realism to the interpretation of military power is not new, - Paolo Rosa applies the theory of neoclassical realism to one of the elements of military power - the analysis of military doctrines (See Rosa 2018), however, this article discusses the broader possibilities of applying the theory. Substantiation of intangible resources and unit-level variables ${ }^{1}$ and, more specifically, the influence of security policy makers' perceptions on the structure of military power, it is assumed that neoclassical realism allows to reveal the process of military power conversion. The application of the theory of neoclassical realism via the use of the intervening variable allows analytical research and disclosure of how the perception of the security environment changes the structure of military power, in other words, to illustrate the empirical process of extracting resources and converting them into actual military power.

However, the theory is of limited application in disclosing the content of military power. Application of the theory of neoclassical realism to the study of military power solves two methodological challenges, reflecting the limited application of the theory: the first is related to an attempt to define the limits of the theoretical interpretation of military power; the second - with the definition of an intervening variable, by determining which content of solution-makers (actors) in the perception of the security environment affects the structure of military power. Thus, in the most general features, the interpretation of the structure of military power is based on the paradigmatic framework of neoclassical realism, however, some theoretical elements such as military power resources are defined by the theory of the force employment by the offensive-defence balance theory representative Stephen Biddle, and via the literature of military studies.

The first methodological challenge. In order to define the limits of theoretical interpretation of military power, the interpretation of military power is based on the synthesis of power as a perspective of resources (See Schmidt 2015; Mearsheimer 2001; Duffield 1995; Waltz 1979; Morgenthau 1967) and power as a relationship (See Baldwin 1989; Barry 1976; Dahl 1957; Nagel 1975; Oppenheim 1981; Tedeschi, Bonoma 1972). The article defines military power in terms of resources, while maintaining the theoretical assumptions that the conversion of resources into desired outcomes, i.e. the conversion of potential military power into actual military power, depends upon the perception of the security environment. From this perspective, it is assumed that power as a resource and power as a relationship are closely linked: power resources, both tangible and intangible, create a power relationship, and military power is perceived as encompassing not only material but also intangible resources, in addition to being contextual in nature.

The theory of the force employment is used in defining the resources that make up military power (the content of military power), on the basis of this theory, military power consists of physical and intellectual/conceptual elements. At the same time, the theory of the force employment emphasises that moral and/or leadership elements are attributable to intangible resources of military power, but does not provide a more detailed interpretation of what intangible resources (See Biddle 2006) other than the intellectual/conceptual element can be included in the military power structure. In order to broaden the definition of intangible resources of military power, a military studies perspective is applied, highlighting the importance of the moral element in the structure of military power.

\footnotetext{
1 Unit-level variables - internal state variables that determine whether and how the state responds to international system pressure. Representatives of neoclassical realism usually distinguish four groups of unit-level variables: (1) image of the leader, (2) strategic culture, (3) internal institutions, and (4) state-society relations. Each of these variables affects three processes: (1) perception of the international system, (2) decision making, and (3) mobilising resources or implementing policies | (Lobell et al., 2009, 13).
} 
The second methodological challenge is to determine the actors whose content of the perception of the security environment have an impact on military power. The theory of neoclassical realism is applied to the analysis of foreign policy decision-making, therefore, the variable of perception of the security environment distinguished in the theory includes the content of the perception of the political elite (Dyson 2010: 243). In this article, in defining the actors the content of the perception of the security environment of which determines the change of military power, theories explaining military innovations disclosing the process of changes in the structure of military power are used. The analysis of the scientific debate between the perspectives explaining military innovations provides a basis for substantiating the influence of the perception of the security environment of both the political and military elites on the change in the structure of military power. A hybrid model explaining military innovation, combining the theoretical insights of Barry Posen and Stephen Rosen, is used to show the interaction between the domestic and structural variables in the state and to reveal how political and military elites use power resources to build military power. In accordance with this model, the change in the structure of military power depends upon the perception of the security environment of the political and military elite: by changing the concepts of warfare and the force employment, they are introducing military innovations, and military doctrines are a means of power conversion, conveying the perceptions of the security environment and changing the structure of military power through them.

It should be noted that the article does not seek to position military power in the general context of the state power, and therefore does not engage in debates about the importance and influence of military power, maintaining the theoretical attitude that military power is an important but not the only source of state power.

\section{Interpretations of the concept of military power}

\subsection{Interpretation of military power from the perspective of realism}

In order to define the resources of military power, it is first worth discussing the primary problem encountered in the analysis of military power, namely, the diversity of terminology used to describe military power. The most commonly found terms related to military power are found in the literature of military studies: 1) military power (See Horowitz 2010; Biddle 2006: 2) military capabilities (See Hinge 2000; Newell 1991: 3) (military) fighting capabilities, war-fighting capabilities (See Jäppinen et al. 2010; Cordesman 2002); 4) fighting power, war-fighting power (See Desch 2008; Gray 2013). The term "capabilities" is often used as a synonym to describe the power or army-related (material) resources available to the state - regardless of the ability of players to influence the military outcome (See Organski 1980; Layne 2006; Sullivan 2007; Desch 2008). Thus, all of these concepts, despite the translation differences between "capabilities" and "power," reflect the same goal: "the army's capability to conduct military activities - assigned tasks, functions and engagement in order to achieve national military objectives" (See Lithuanian Military Doctrine 2016: 27; Doctrine of the armed forces of the Slovak Republic 2003: 2; UK Defence Doctrine 2014).

The definition of military power in the context of theories of realism presents a fundamental challenge in determining what resources constitute military power. The traditional perspective of realism highlights the importance of material elements such as armaments, human resources, the defence part of the state budget and advanced military technologies (Raitasalo 2005: 98-99). Some of the most commonly used quantification measures of military power include the Composite Indicator of National Capability, consisting of six criteria: military expenditures, size of military personnel, energy consumption, iron and steel production, urban and total population ratio (Singer 1988).

On the other hand, a significant volume of research emphasises the limitations of material resource-based methods of measuring military power in predicting or interpreting the results of military action. The methodology of war correlates has been criticised as not providing a basis for determining why terrorist organisations such as al-Qaeda or the Islamic State generate effective military power without having sufficient material resources. Methodologies that assess purely material military capabilities are inappropriate and analyse why stronger actors in international relations lose wars or face challenges in overcoming much weaker opponents, for example, 
as the US in its fight against rebels in Afghanistan armed with light weapons (See Arreguin-Toft 2005: 97; Biddle 2006: 20-23; Stam 1996: 73; Bennett, Stam 1998; Sullivan 2007).

According to an empirical study by Stephen Biddle, the material resources of military power - gross domestic product, population size, human resources, military spending - were not sufficient to predict more than 60 per cent of results of military conflicts. According to Biddle, "the empirical study of politics thus depends on measures of capability, which play a pivotal role in the war causation, arms racing, alliance formation, conflict duration, crisis escalation, or deterrence literatures, among others. Yet the standard capability measures at the heart of all this are actually no better than coin flips at predicting real military outcomes. An enormous scholarly edifice thus rests on very shaky foundations (Biddle 2006: 2). <..> On average, flipping a coin would predict the outcome 50 percent of the time; a powerful theory should outperform a coin toss by a wide margin. Yet none of the five indicators predicted more than about 60 percent of the cases" (Biddle 2006: 21).

Given the limited explanatory power of methods for measuring military power based on material resources, academics have begun to incorporate intangible resources into the structure of military power. For example, Biddle notes that "Capability is not primarily a matter of materiel. It is chiefly a product of how states use their material resources - and this varies widely in ways that are not mere epiphenomenal reflections of materiel constraints" (Biddle 2006: 192). Emily O. Goldman and Leslie C. Eliason also note that "it is the way militaries take raw technologies and use them that creates military force" (Goldman, Eliason, 2003). The insights of scholars can be based on the importance of intangible resources in predicting victory in war, which has long been highlighted in military studies (Hironaka 2017: 44-46): Sun Tzu urged soldiers to know their enemy and themselves by attacking the enemy's weaknesses and avoiding the strong sides, and, while noting the deception during the war, stated that leadership professionalism is the ability to manipulate the enemy's will to achieve the desired result without a fight. Clausewitz pointed out that war is a "collision between two living forces," thus emphasising the dynamic and interactive nature of war rather than the mechanical clash of material resources or technology (Gentry 2011: 12).

It should be noted however that even academics who prioritise material resources of military power, such as Waltz, admit that while material resources have a significant impact on results, the army's skills can also influence military power (Waltz 1979: 131). This attitude is typical of some representatives of the realism tradition: Morgenthau has noted that "Since the emergence of the modern state system in the fifteenth century, no single nation has succeeded in imposing its will for any length of time upon the rest of the world by sheer material force alone" (Morgenthau 1967: 156-158). Thus, "Morgenthau did not follow a straightforward conception of materialistic power. $<\ldots>$ In order to maintain the stability of the international system, to achieve peace and security, the mechanical distribution of powers is not enough, it requires common moral provisions and political principles" (Jakniunaite, 2011: 14). In the context of realism theories, neoclassical realism attaches the utmost importance to the inclusion of intangible elements in the interpretation of power (Schmidt 2007, cited in Berenskoetter, Williams 2007: 49).

The literature on security studies often emphasises that the use of military material resources is largely determined by strategies for the use of military force, such as military doctrines (See Gow 2006; Rotte, Schmidt 2003; Arreguín-Toft 2005; Stam 1996). One of the first proponents of this approach was Richard McMurry, who analysed the causes of military effectiveness during the U.S. Civil War and, more specifically, the behaviour of different actors and the impact of this behaviour on military efficiency (McMurry 1989: 117). The strategy used by the army may contribute to or undermine the proper use of material resources of military power (See Stam 1996; Arreguín-Toft 2005; Lyall, Wilson 2009). Military doctrines are shaped by threat perceptions (Ka Po 2004: 6) and identified as a means of regulating material military resources: the doctrines indicate how the state will use its army during the war, how military operations will be prioritised, etc (Gallo 2018: 10).

The interest of the representatives of realism in military doctrines is best reflected in theoretical insights of Barry Posen. In defining military doctrines Posen states that military doctrine is intended to set the priorities of the state and to prioritise and write down the structure and use of the army (Posen 1984: 13). Prioritisation 
allows the synchronisation of different types of military forces (land, sea and air) under the authority of same state. At the same time, the inclusion of priority in the definition is the recognition that military doctrine is the result of the interests of the organisation. Determining the structure and usage makes it possible to find a balance between the threats to the state and the available resources: threats can be many and resources are nearly always limited (Gallo 2018: 31-32).

It can be argued that military doctrines reflect the ways in which material resources are used to build military power. These insights are reinforced by the theory of the force employment by Stephen Biddle, a promoter of the defence-offensive balance. By choosing medium- and high-intensity conflicts as the subject of his research and distancing himself from low-intensity conflicts and global conflicts involving the use of weapons of mass destruction, Biddle analyses how different use of material resources in conventional military operations alters the outcome of the battle (Cohen 2005: 414-415). The study confirms that the doctrines and tactics under which the armies use their material resources on the battlefield are a key determinant of military power (Biddle 2006: 2). Although Biddle does not distance himself from the importance of material resources, he emphasises that "This in turn means that states' relative economic, demographic, or industrial strength are poor indicators of real military power: gross resource advantages matter only if they can be exploited via modern-system force employment, and many states cannot do so" (Biddle 2006: 3). He also notes that "In fact, much of the history of post-1900 tactics and doctrine has been precisely about the need to respond to these changes and how best to do so" (Biddle 2006: 197). Thus, the insights of Posen and Biddle can be contrasted to the insights of Zakaria, a representative of neoclassical realism, in separating national and governmental powers via the process of extracting resources. In his theory, Biddle, highlighting the special importance of military doctrines in the structure of military power, essentially sees them as a means by which potential military power is converted into actual military power.

The theory of the force employment in the context of military studies is not new: Clausewitz argued that "numerical superiority was a material factor. It was chosen from all elements that make up victory because, by using combinations of time and space, it could be fitted into a mathematical system of laws. It was thought that all other factors could be ignored if they were assumed to be equal on both sides and thus cancelled one another out. That might have been acceptable as a temporary device for the study of the characteristics of the single factor; but to make the device more permanent, to accept superiority of numbers as the one and only rule, and to reduce the whole secret of the art of war to the formula of numerical superiority at a certain time in a certain place was an oversimplification that would not have stood up for a moment against the realities of life" (Clausewitz 1993: 134-135). The importance that Clausewitz has attached to the force employment is also gaining the support of the military elite, for example, US General Stanley McChrystal, "using force employment methods is necessary to optimizing resources to achieve military objectives because it establishes high levels of connectivity, which is referred to as "single consciousness" (Decker 2015: 112).

The theory of the force employment in political science is often ignored for several reasons. On the one hand, it is easier to assume that states use their material resources optimally. By this logic, material resources become the only important variable defining military power (Glaser, Kaufmann 1998: 55-57). Classical realists Morgenthau and Knorr alluded to strategy as an element of military power in their work, however focused on the quantification of material resources (Ruffa 2008: 6-8). On the other hand, the inclusion of intangible resources in the structure of military power increases the difficulty of measuring military power. John S. Duffield emphasises that "qualitative factors are much more difficult to measure than is force structure, and their contribution to capability is commensurately harder to assess in the absence of actual combat experience" (Duffield 1995: 13). Even significant material resources, such as the size of the enemy's army or the number of nuclear weapons, are difficult to quantify, and intangible elements are even more difficult to estimate (Hironaka 2017: 44-46).

Despite differing scholarly opinions on the methods of estimating intangible resources and their role in the structure of military power, Biddle's theory concerning the force employment is an important starting point for defining the content of military power by incorporating intangible resources into the military power structure and justifying a hierarchy of military-powered resources. In the theory of the force employment, military 
doctrines and tactics are considered to be the most important element of military power, regulating the ways of using material resources. This theory provides a basis for interpreting military power as the result of the interaction of tangible and intangible resources, while also raising two fundamental problems.

First, Biddle identifies military power as a synthesis of physical and intellectual/conceptual ${ }^{2}$ elements, although alludes that moral and/or leadership elements are attributable to intangible resources of military power (See Biddle 2006). however, the analysis does not provide a more detailed explanation of what intangible resources, other than the force employment, may be included in the military power structure. On the one hand, Biddle did not seek to define the totality of the resources that make up military power, instead, his purpose was to justify the importance of the force employment in the structure of military power. Biddle, on the other hand, has been criticised by Lawrence Freedman claiming that one of the weaknesses of this theory is the lack of a definition of what intangible resources make up military power (Freedman 2005: 432).

Second, by assigning to his military doctrines and tactics the hierarchically highest position in the structure of military power in regulating the use of material resources, Biddle suggests that in analysing military power it is expedient to separate the military power resources from actual military power that defines the state's ability to use available resources when analysing military power. In this respect, Biddle's theoretical insights highlight the expediency of applying the theory of neoclassical realism to the analysis of military power: it is assumed that the potential of military power (available material resources of military power) is adapted to the existing security environment via military doctrines, i.e. converted into actual military power. In the theory of the force employment, this process is not disclosed in detail, therefore it makes sense to use the literature on military studies.

\subsection{Interpretation of military power from the perspective of military studies}

In the context of military studies, the structure of military power resources is inseparable from the principles of war formed by General John Frederick Charles Fuller, based on three spheres of power: physical, moral, and cognitive. Fuller attributed military technologies or military means to the physical sphere, intellectual effort and preparation of war plans to the cognitive sphere. The easiest-to-identify sphere, according to Fuller, is the physical sphere: "The physical sphere is, in fact, the alphabet of war," (Fuller 2012: 174) and the most difficult to be identified the moral sphere, as it includes soldier motivation and other elements that encourage combat, defining the moral sphere as "the moral sphere is the domain of the soul, ego, or "heart" - there is no just name for this element-and this, I think, alone shows how complex this sphere is" (Fuller 2012: 15). Fuller perceived the relationship between the moral and physical spheres as multifaceted - the moral sphere increases the fighting power of the physical component (human resources), and the improvement of the physical component has a positive effect on the moral sphere. It is worth noting that Fuller's approach to military power reflects the ideas of neoclassical realism: perceiving power as a resource, Fuller points out that actual military power is determined by its use for specific purposes (Fuller 2012: 15). In other words, military power is defined not only by the resources available to the state, but also by the ability to extract and use those resources.

The principles of war formed by Fuller had a great influence on the development of military thought - one of the first attempts to conceptualise military power in military doctrines was the Field Service Regulations of the U.S. Army published in 1924 where the Fuller's war principles were enshrined as general principles of combat (Boslego 1996: 11-12). In the early military doctrines of the $20^{\text {th }}$ century, the spheres of power formed by Fuller as defining the structure of military power were not consolidated, but the evolution of military thought highlighted a holistic approach to military power, and military power began to be perceived as a whole of factors affecting the ability of armies to accomplish the tasks (Boslego 1996: 13). In addition to Fuller's ideas, representatives of the US military thought have also begun to place more emphasis on the importance of intangible elements of military power (Boslego 1996: 11-12). While the importance of intangible elements of military

\footnotetext{
Stephen Biddle does not specify the intellectual/conceptual element in his theory of the force employment, but the components of the intellectual/conceptual element highlighted in the previous section, one of which is military doctrines, give reason to believe that the concept of force employment can be equated with an intellectual/conceptual element of military power.
} 
power in the military doctrines of the $20^{\text {th }}$ century has gradually increased, the incorporation of the moral element of military power into the structure of structure of military power has begun at the latest in the US not until 1986 (for example): Field Operations Manual 100-5 highlights the importance of the moral factor in warfare. Intangible elements such as leadership, cohesion, morality, courage, skills are equated in this doctrine to the importance of the physical element - the quantity and quality of material resources (Richardson 1986: 6).

In the second half of the $20^{\text {th }}$ century, the spheres of power formed in Fuller's theory were incorporated into the military doctrines of different states by defining the structure of the military resources. In 1988, the first written British Military Doctrine defined military power as "the ability of a military organisation to fight" (Mäder 2004: 95-96) and divided it into three elements: interactions between intellectual/conceptual, moral and physical (Mäder 2004: 95-96). It is worth noting that all versions of the UK defence doctrine reflect the inertia inherent in military documents - the structure of resources that make up the backbone of military power, perceiving military power as a synthesis of conceptual/intellectual, physical and moral elements, transferred from one doctrine to another. The structure of military resources comprising the military power in the UK defence doctrine in 2014 is visualised in Fig. 1.

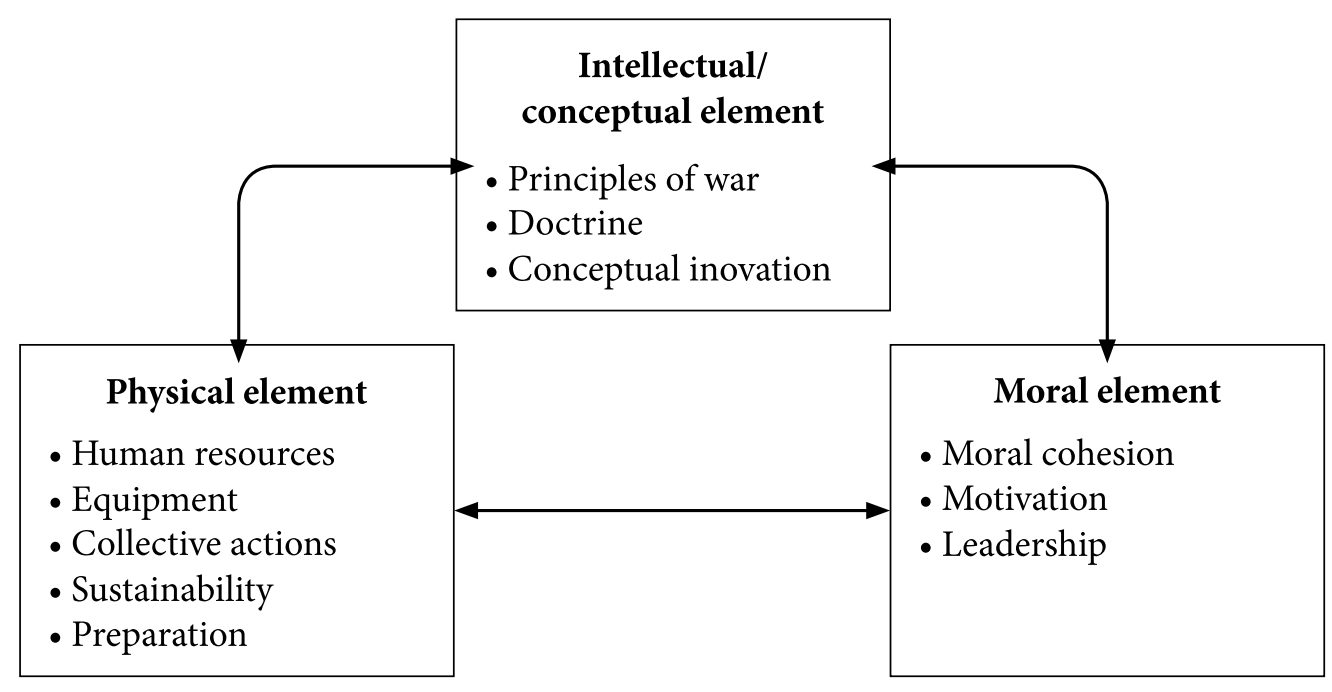

Figure 1. Structure of military power in the UK's defence doctrine

Source: UK Defence Doctrine 2014, 25.

The intellectual/conceptual element includes the development of military thought - military doctrine in a broad sense: intellectual debate, doctrine development, transfer of ideas into teaching. This element "The conceptual component provides a framework of thinking within which military personnel can develop understanding about both their profession and the activities that they may have to undertake" (UK Defence Doctrine 2014: 25). The physical element includes combat measures such as human resources, equipment, collective action, sustainability, and preparedness. The moral element - the ability to attract human resources for fight - moral cohesion, motivation and leadership. The doctrine emphasises that "Warfare is a human activity and the moral component exerts a decisive psychological influence, both individually and collectively. While morals (principles of right and wrong) is one aspect which enhances cohesion and morale (a sense of confidence and wellbeing) is another which promotes courage and commitment, the moral component is considerably broader" (UK Defence Doctrine 2014: 31).

All three elements of military power are closely interrelated: the intellectual/conceptual element includes the moral element - the leadership, motivation, or ethical constraints imposed in military doctrines are derived from the moral element. The moral element is closely blended with the physical element - it reflects how soldiers, both individually and collectively, apply their intangible resources - intellect, emotions, motivation and leadership to combat (UK Defence Doctrine 2014: 25). The UK Army Doctrine Publication - Land Operations also emphasises the close interaction of the intangible elements of military power - intellectual/conceptual and 
moral - with the material (physical) element. "Assessment of fighting Power is both quantitative and qualitative. Much of the physical component can be quantitatively measured. This constitutes the visible combat power of a force and informs force ratio assessments, and so contributes to understanding relative capabilities. On the other hand, the moral and conceptual components tend more to subjective, qualitative assessment. The three components are interdependent, although which, if any, is pre-eminent depends on the situation" (Land Operations 2016: 3-1).

A detailed review of the military doctrines of different NATO countries shows that the intellectual/conceptual, moral and physical elements are defined in a similar way, for example, in the Slovak military doctrine, military power consists of: 1) the moral component, which includes motivation, values, leadership, management; 2) the intellectual/conceptual component, encompassing war principles, military doctrine, war theories and practices, and 3) the physical component, encompassing human resources, weapons and supplies, operational readiness, sustainability and collective work (Doctrine of the Armed Forces of the Slovak Republic 2003: 15). Lithuanian military doctrine also emphasises that military power depends upon three interrelated components (Lithuanian Military Doctrine 2016: 28).

The intellectual and conceptual element in this doctrine includes the "ideas on how to develop capabilities and act, the intelligence and knowledge of soldiers. Principles, concepts and doctrines of war that define the professional thinking and behaviour of the army personnel in the performance of military tasks, functions and assignments" (Lithuanian Military Doctrine 2016: 3-3 - 3-4). The doctrine stresses that "this part of the military power is considered by the army to be some of the most important, as military capabilities (competencies) and appropriate training of the army are based on new military ideas" (Lithuanian Military Doctrine 2016: 3-3 3-4). The moral element includes "the will, conduct, and esprit de corps of soldiers. The determination of soldiers and their determination to perform military tasks, functions and tasks - to fight and sacrifice and to follow the norms of law" (Lithuanian Military Doctrine 2016: 3-3 - 3-4). Physical and technical element - "soldiers, military equipment and other resources" (Lithuanian Military Doctrine 2016: 3-3 - 3-4).

At NATO level, the structure of the resources that make up military power is also defined as the interaction of physical, intellectual/conceptual and moral elements. For example, in the Allied Joint Doctrine for Land Operations of 2016, the intellectual/conceptual component includes "Doctrine forms part of the conceptual component. Theories of warfare always influence how information is perceived and processed" (Allied Joint Doctrine for Land Operations 2016:2-13-2-14). The doctrine emphasises that "Therefore, even if the will and the ability to fight are well developed, deficits in this component will lead to ineffective or counterproductive use of fighting power" (Allied Joint Doctrine for Land Operations 2016: 2-13 - 2-14). The moral element reflects the persuasion of the Alliance forces to fight and involves the "moral component of fighting power concerns persuading Alliance forces to fight. It is measurable by good morale and depends on the convincing all that the Alliance's purpose is morally and ethically sound, thus promoting an offensive spirit and a determination to achieve the aim. $<\ldots>$ The moral component also includes belief in the justness of the cause being fought for and the ability to maintain the support of a nation's population. Finally, it includes conducting operations according to the laws of armed conflict. Violating these laws weakens the moral component of the force, alienates the population of the country being fought in, and erodes support for the effort among the populations of allied nations" of soldiers (Allied Joint Doctrine for Land Operations 2016: 2-13 - 2-14). The physical element is the means of combating, which include "the physical component. The physical component of fighting power is the means to fight. It has five elements: manpower, equipment, collective performance, readiness, and sustainability. It is the combination of people and training, both as individuals and teams, with the vehicles, aircraft, associated weapons, sensors, and other equipment, and their effective deployment, sustainment, and recovery" (Allied Joint Doctrine for Land Operations 2016: 2-13 - 2-14).

Thus, comparing the military doctrines of NATO and NATO members, it can be seen that the structure and definitions of the physical and intellectual/conceptual elements are essentially identical in many military doctrines, and the structure of the moral element can be twofold- directed at the personal characteristics of the soldier, such as spirituality, rationality, motivation and/or command elements - leadership, management (See Porter 2007; 
Cox 2011). Whereas the structure of military power enshrined in the military doctrines of Allies is not fundamentally different and reflects the structural level - NATO's military doctrines, military resources can be defined as the interaction of physical, intellectual/conceptual and moral elements, in which the intellectual/conceptual element consists of military doctrines and war theories, physical element of human resources, equipment, collective action, preparedness and sustainability, moral element of motivation, leadership and management.

\section{Interdisciplinary interpretation of military power}

In order to form an inter-pararadigmatic interpretation of military power and taking into account the resources of military power found in the literature of military studies, it is appropriate to attribute a moral element to intangible resources of military power, in addition to the intellectual/conceptual element of military power. The assessment of the importance of the moral element in warfare has deep historical roots and the insights of different Western and Eastern theorists have demonstrated that the moral element is far from a new attribute of military power. Dar Sun Tzu (Sun Tzu, 1971: vii) wrote about the importance of the moral element in warfare: "If you know the enemy and know yourself, you need not fear the result of a hundred battles" (Sun Tzu, 1971: 9). Clausewitz also singled out the moral element: "They are the spirits which permeate the whole element of war, and which fasten themselves soonest and with the greatest affinity to the will which puts in motion and guides the whole mass of powers, unite with it as it were in one stream, because it is a moral force itself" (Clausewitz 1993: 139) French Colonel Charles Jean Jacques Joseph Ardant du Picq, describing the wars of Friedrich the Great and Napoleon from a combatant's point of view, concluded that part of the moral element, cohesion, allowed the army to defeat an opponent superior in its physical resources (Ardant du Picq 1987). Samuel Lyman Atwood Marshall renewed the Du Picq's combat assessment methodology in his analysis of World War II and concluded that military cohesion improves communication and training, troops (Marshall 1978: 37-38; 173).

The experience of the First World War and related technological and strategic changes, demoralisation of soldiers, the emergence of psychological disparities in the military, and the political, social and cultural aspects of societies in the interwar period encouraged the militaries to pay more attention to the influence of psychological factors in the war against the Second World War. At the beginning of World War II, a moral committee was established in the army of the UK; the USA also began to pay more attention to the moral element in warfare, and the motivational aspects of soldiers began to be incorporated into military doctrines. In addition, many US and European military academies have developed departments of behavioural sciences, leadership and command (Kellett 1982: 14).

Ekkehart Lippert, explaining his interest in the influence of the moral element on military power, notes that the nuclear bomb has caused a military stalemate because of its very nature of a weapon and the prospect of mutual self-annihilation. In order to reshape the balance of deterrence, more intensive search has been taken to move away from the prospect of nuclear war. This reorientation was aimed at giving greater importance to the army and soldiers. Thus, the perspective of optimisation of human resources has become a focus. This perspective was promoted not only by the nature of the Cold War, but also by the declining birth rate and the associated problem of maintaining human resources in the army (Lippert 1998: 33, cited in Gaub 2010: 10).

In the interdisciplinary framework, the moral element was mainly a focus of military sociologists, linking the moral element not so much to the analysis of military power as to the research on the effectiveness of the army (Chacho 2001; Marshall 1978; Henderson 1985; Little 1964). In the field of political science, Niccolo Machiavelli has emphasised that the ethnic composition of the army can affect the overall morale and functioning of the army, as well as state security (Machiavelli, 1994: 8-12; 40-48). The onset of research on the moral element of military power can be linked to the analysis of the motivation of German and US soldiers to fight in World War II (Shils, Janowitz 1948; Stouffer et al 1949, cited in Brooks, Stanley 2007: 5). These studies were concentrated on explaining the factors affecting the efficiency of the army and covered aspects such as professionalism of soldiers, social solidarity, code of honour, esprit de corps, cohesion, collective discipline, operational and combat morality (Kümmel, 1999: 19-27). Tom Henderson McGuffie, Charles C. Moskos, David R. Segal and Wallace H. Sinaiko studied the morality of soldiers of different military ranks from a historical perspec- 
tive (McGuffie 1964; Moskos 1970; Segal, Sinaiko 1987). Edward Shils and Morris Janovitz showed in their research that an effectively functioning army is the one whose soldiers have a high level of cohesion. According to them, ideology, propaganda and political aspects were far less important in maintaining the combat effectiveness of the German army than the cohesion of a small combat group (Shils, Janowitz 1948). Omer Bartov highlighted the importance of moral disposition and the honour of risking one's life on behalf of the state in the army (Bartov 1991, cited in Brooks, Stanley 2007: 5). Charles Moskos analysed a latent ideology that reflects the universal value of the social system for which soldiers are fighting - a clear ideological commitment can be the driving power behind the moral element (Moskos 1970). Some sociologists emphasise the importance of military discipline, courage and nationalism (Castillo 2001).

Thus, complementing Biddle's theory of the force employment, the interdisciplinary structure of military power can be defined as embracing physical, moral, and intellectual/conceptual elements (see Fig. 2).

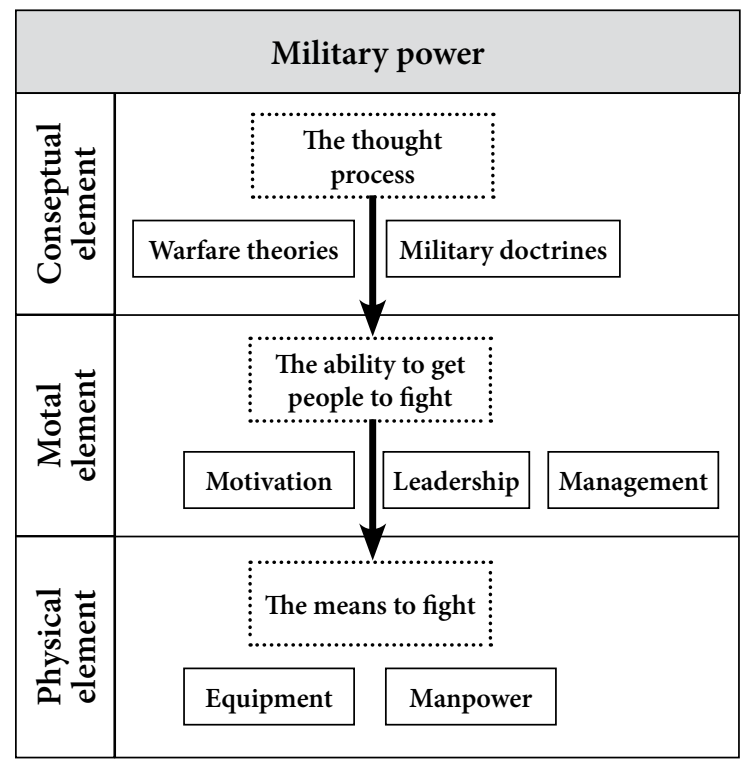

Figure 2. Theoretical model of the structure of military power

Source: created by the author according Allied Joint Doctrine for Land Operations 2016, 2-13 - 2-14 and UK Defence Doctrine 2014.

The intellectual/conceptual element has the greatest significance in the structure of military power, as it regulates the ways of using material resources. Biddle's theory provides a framework for hierarchising only the physical and intellectual/conceptual elements of military power. By incorporating a moral element into the structure of military power, the arrangement and interaction of these elements can be complemented by the hierarchy of elements of military power in the defence doctrine of the United Kingdom. The doctrine emphasises that the physical and moral elements of military power depend directly on the intellectual/conceptual: the theories of military doctrine and war regulate not only the use of the physical element but also the adaptation of the moral element to the existing security environment and the nature of warfare (Sloan 2012: 243). Thus, the moral element intervenes between the intellectual/conceptual and the physical elements, managing the ways in which forces are used (intellectual/conceptual element) and the human resources used (physical element).

\section{Influence of military innovations on the structure of military power}

Fuller also pointed to the fact of perceptions of the security environment on the structure of military power, noting that military doctrines are a tool to help a military organisation adapt to changes in the security environment by defining military doctrines as "the central idea that at the given time, as affected by strategic circumstances, actuates an Army" (Fuller 2012: 30). In today's military doctrines of NATO and NATO member states, the not only the resources that make up military power, but also the importance of adapting those resources to the 
existing security environment are highlighted in the definition of military power. For example, the 2016 NATO standard Allied Joint Doctrine for Land Operations AJP-3.2 states that "Fighting power reflects the actual state of a force at any given time. It results from the entire process of force generation - the equipping, training, doctrine, morale and other factors that deliver a force to a commander, ready and capable of action" (Allied Joint Doctrine for Land Operations 2016: 2-13). United Kingdom doctrine emphasises that "When assessing the situation, our commanders must understand the context in which they are applying fighting power" (UK Defence Doctrine 2014: 27), While the Army Doctrine Publication. Land Operation of the United Kingdom emphasises that military power is a conditional, not an absolute concept: "A force optimised to fight and operate in a single environment may not have the appropriate balance of fighting Power to operate elsewhere" (Land Operations 2017: 3-2).

The Army Doctrine Publication "Land Operation" of the United Kingdom places particular emphasis on the influence of the environment on military power: "The environment in which land forces are used and for which they are prepared also has a significant bearing on their actual fighting Power. Given the uncertainty of where, against whom and with whom operations might be conducted, land forces require mental and physical preparation to operate in a range of environments. $<\ldots>$ When fighting Power is developed to deal with the complexities of the most demanding operational environments, a force increases its potential to adapt rapidly to new situations" (Land Operations 2017: 3-2).

The importance of perception is emphasised in Lithuanian military doctrine. Perception is defined as "the capacity to understand, describe, influence the current and future environment and its context, [which] helps to determine what the army should be (what competencies it should have and for what challenges it should be prepared in present and in the future) and how its forces and various military units should act during operations and missions to affect the perception of the local population and opponents of the environment and its phenomena" (see Fig. 3) (Lithuanian Military Doctrine 2016: 3-4).

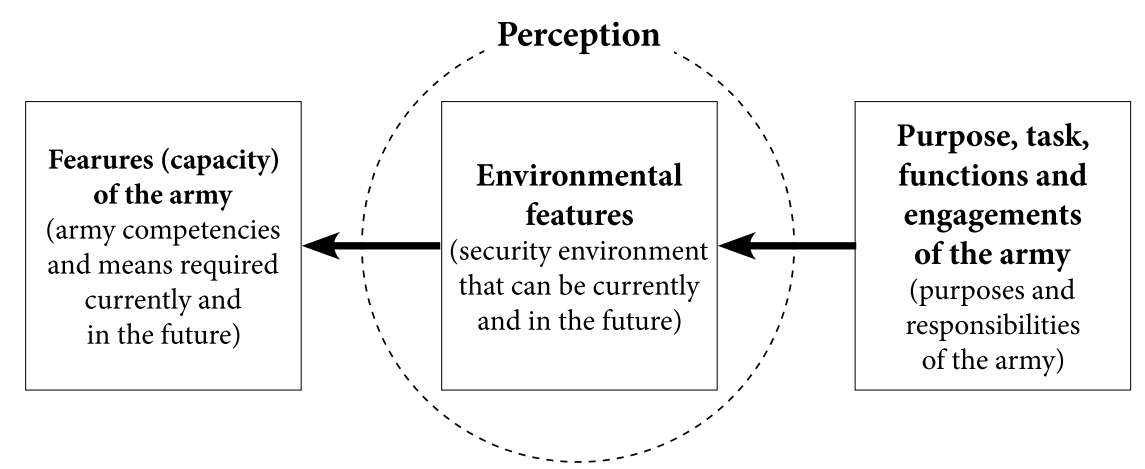

Figure 3. Influence of the perception of security environment on military power

Source: Lithuanian Military Doctrine 2016, 3-4.

The military doctrines of other NATO Member States do not single out the influence of the perception of the security environment on military power, but emphasise that the intellectual/conceptual element of military power - military doctrine and military theory - is a tool to adapt military power to the existing security environment. Such tendencies can be seen in the military doctrines of Canada (Canadian Military Doctrine, 2009), Slovenia (Slovenia Military Doctrine 2006), and the Netherlands (Netherlands Defence Doctrine 2013). It can be summarised that military power depends not only on the resources available to the state, but also on the ways of using these resources (perception of the security environment), conveyed via the intellectual/ conceptual element.

Theories explaining the influence of the security environment on the structure of military power makes it possible to reveal military innovations. These theories make it possible to explain how the challenges posed by the security environment are institutionalised in military doctrines and become part of military power. According 
to Rosen, new theories of military victory are the outcome of the "perception of change in the structure of the international security environment" (Rosen, 1991: 57) of military commanders, while military innovations involving fundamental changes (Wilson 1989: 222) in doctrine, tactics, and/or organisational structure reflect the use of available resources by military organisations to create military power (Goldman, Leslie 2003). Military innovation is the identification of the types of military tasks to be performed or major changes to existing tasks during a warfare (Zisk 1993: 4). According to James Q. Wilson: "innovation is not any new program or technology, but only those that involve the performance of new tasks or a significant alteration in the way in which the tasks are performed" (Wilson, 1989: 225).

Military innovations are often confused with the army adaptation. Theo Farrell defines military innovation as "In contrast, I understand military innovation to be a major change that is institutionalised in new doctrine, a new organisational structure and/or a new technology," (Farrell 2010: 569) and military adaptation - as "as change to tactics, techniques or existing technologies to improve operational performance" (Farrell 2010: 569). Innovation must be "innovation has to have considerable bearing on the organization in both breadth and scale" (Grissom 2006: 907). Major technological changes are often considered to be innovations, but attributing these changes as innovations is controversial, unless they fundamentally alter military tactics, doctrines and/or organisational structure (Wilson 1989: 222). Academic literature emphasises that technological inventions are not innovation per se. According to Dima Adamski, technological innovation is important "while the technological component is often an important initial condition, a true revolution depends on confluence of weaponry, concept of operations, organization, and the vision of future war" (Adamsky 2010). Adaptation of the army reflects a slight change in the army - changes in tactics, methods and procedures to improve performance that require no changes in military doctrine (Farrell 2010: 569). Over time, adaptive changes of the army can be incorporated into military doctrines, promoting important changes in structure, training, and/or material resources. In this case, military adaptation becomes a military innovation (Jordan 2017: 210).

It should be noted that military innovation is not only linked to changes in the security environment. The literature of political science highlights a wide variety of sources that drive military innovation, including structural factors such as technology, geography of predicted battlefields, nature of alleged threats, and the balance of power in the international system, as well as domestic (unit level) variables such as the nature of relations between civilians and militants, corporate culture, competition between different army units, competition between army branches, influence of military leaders (Gallo 2018: 10). Representative of neoclassical realism Paolo Roso notes that military innovation is influenced not only by the international security environment, but also by the interests of the military organisation and the subculture, the perception of war by politicians and international politics (Rosa 2018: 25). Stephen Rosen, Thomas Ehrhard, Barry Posen, Stephen Biddle confirm that perceptions of the security environment and domestic policy introduce new variables into the interpretation of military innovation (O'Hanlon 2019: 20). The perspectives interpreting military innovations can be divided into several subgroups: military-civilian model (power balance access), intraservice access, interservice access and cultural access (Gallo 2018: 49).

Barry R. Posen emphasises the influence of systemic factors on military power. Doctrinal changes depend on threats and changes in the balance of power, technological developments, geography of future battlefields (Gallo 2018: 50-54). States operate in an anarchic system that encourages the maximisation of power for survival. From this perspective, military doctrines are a consequence of the influence of the international system: by perceiving the changing nature of threats or the changing balance of military capabilities, political leaders engage in development of innovation (Posen 2016: 159). According to Terry Terriff and Theo Farrell, "Military change is a rational response to changing strategic circumstances; states adopt new military practices, and emulate best military practice, in order to keep up with the competition" (Farrell, Terriff 2002: 270; Waltz 1979: 127; Posen 1993: 82). In addition to the importance and influence of the security environment, the influence of the environment of military operations on doctrinal innovation is also deemed to be important. Learning from experience acquire in an operational environment one can act as a mechanism for implementing and enhancing military innovation. Military operations enable armies to test and elaborate military doctrines, structures and technologies, help identify critical military capabilities and understand the nature of future wars (Farrel et al 2013: 13). 
According to Posen, in the conditions of high threat to the state, the involvement of civilians in doctrinal changes is dispensable. In times of crisis, the political elite promotes military innovation based on a realpolitik perspective and shifting the organisational interests of the military and its propensity to avoid change. In a period of low threat, military organisations can independently develop doctrines without intervention of the political elite. The influence of political leaders can be direct - either by demanding changes in military leadership, or indirect - by helping the military elite having experience in implementing doctrinal innovation and convinced of the need for innovation. Posen calls this military elite mavericks, promoting change in military institutions directly or indirectly (Posen 1984: 16; 233; 174-175). Thus, from this perspective, systemic change and the involvement of political leaders in regulating the army's adaptation to the strategic environment are inseparable elements of military innovation.

The second school of interpreting doctrinal innovations is the organisational model. Stephen Rosen, a representative of this perspective, defines military innovation as "a change in one of the primary combat arms of a service in the way it fights or alternatively, as the creation of a new combat arm" (Rosen 1991: 7). This definition implies that the focus is primarily made on the interaction of military innovation with changes in organisational structure (Rosen 1991: 2). According to Rosen, "innovation is the product of a process in which senior military leaders develop a new theory of victory in war and they use mid-level officers in the organization to institute innovations that support that theory" (Rosen 1991: 20). Army leaders making changes use their status to influence the organisation and pursue the preferred military innovations. They also take advantage of incentives by obliging mid-ranking soldiers to support the military innovations they offer.

In his theory, Rosen calls into question the importance of political leaders, highlighted by Posen, emphasising that military innovations stemming exclusively from the civilian sphere are doomed to fail. According to Rosen, military innovations arise between army units, divisions, and branches. From this perspective, military innovation is primarily the consequence of a perception of the security environment by the military rather than the political elite, and this is one of the key differences that distinguish these models of innovation. Organisational theory also differs in that it reflects the diversity of interests in military organisations rather than treating organisations as monolithic blocs. Internal differences in an organisation lead to an ideological struggle among theories, which in turn drives innovation. These two elements - the role of innovation in the absence of civilian intervention and inter-unit competition - are Rosen's greatest contribution to the analysis of military innovation (Gallo 2018: 38).

Thus, the most prominent promoters of military innovation perspectives, Posen and Rosen, explain military innovation through competition: the first one bases them as a rivalry among political leaders, the second - as a rivalry among soldiers. The attitude of the following academics towards the army should be distinguished: Posen describes the army as avoiding change, therefore, purely civilian intervention can create these changes (See Posen 1984). On the contrary, Rosen proposes an internal explanatory model for the army, where innovation is driven by competition between services, competition for resources, and pursuit of status between different units (See Rosen 1991: 2). Even though Posen and Rosen disagree on who innovates, when, and how, they both agree that conflicts among groups are the driver of military innovation and seek to determine who - civilian (political leaders) or soldiers - is a decisive factor for military innovation. The hybrid model of doctrinal innovation of Bradd Hayes and Douglas Smith combines together the insights of Rosen and Posen and explores the influence of both soldiers and civilians on military innovation, thus providing more explanatory power to the causes of change in military doctrines. In their study, Hayes and Smith conclude that neither Posen nor Rosen's theory is exclusively dominant, therefore, both civilians and soldiers have a significant influence on doctrinal innovation (Hayes 1994: 97).

The third approach to military innovation involves a model of interaction between different units. The theory is created in the works of Harvey M. Sapolsky, Samuel P. Huntington, and Cote Jr. Owen (See Sapolsky 2002; Sapolsky 1972; Huntington 1961). Cross-sectoral level analysis is valuable in that it allows the interpretation of doctrinal innovation to be founded to include interactions between different actors. The prospect of inter-unit competition allows the focus to be shifted from one military organisation to other military services in the state. 
According to Grissom, such approach is based on the shortage of resources and struggle for them - military units compete to build capabilities for new missions or to upgrade an old mission (Grissom 2006: 919). Thus, armies begin to introduce doctrinal innovations on their own initiative, in addition to unnecessary pressure from the political elite. In pursuit for resources, army units closely monitor the emergence of new needs and missions for the military to ensure control of resources, thus stimulating innovation. From this perspective, institutional inertia, which under normal circumstances is a hindrance to the innovation process, is shrunk when armies engage in bureaucratic struggles over budget allocation (Davis 1967: 21; Cote 1996: 77-78).

The fourth model of military innovation and alliance the importance of strategic and organisational culture for military innovation. Theo Farrell, Terry Terriff, Elizabeth Kier, Dima Adamsky are the main advocates of this theory, arguing that culture influences organisations responses to technological and strategic capabilities (See Farrell 1996; Farrell, Terriff 2002; Adamsky 2010; Kier 1997). According to Farrell and Terriff, culture is a key factor in understanding the goals, strategies, and modus operandi of a particular army. This means that culture drives military innovation, albeit often indirectly. Cultural transformations, both strategic for society as a whole, and for its elites, and organisational in the army, can become an innovation-driving factor (Farrell, Terriff 2002: 7-10). Elizabeth Kier rejects the influence of the security environment highlighted in Posen's and Rosen's theories as an external element driving military innovation. According to Kier, the critically important factor in explaining military innovation is the culture of military organisations (Kier 1997: 144-145). Kier's insights coincide with those of military historian Williamson Murray, giving significant importance to the culture of military institutions in the process of military innovation (Murray 2002: 16-18).

In addition to the main theories explaining military innovation, the bottom-up explanatory models, which interpret military innovation as emerging from the experience of soldiers on the battlefield, are gaining popularity. Adam Grissom draws attention to empirical anomalies that are limitedly explained by top-down models, i.e. innovations arising because of the influence of political and military elites, competition among units (Grissom 2006: 920-924). Although top-down models dominate the field of military innovation studies (Cohen 2004: 400; Farrell 2010; Russell 2011: 623), a growing number of academics note that bottom-up models provide conditions for explaining unit-level decisions in both war and peace conditions, and stress the importance of processes initiated by middle- and lower-ranking soldiers rather than senior military or political leaders (Grissom 2006: 920-924). James Russell, citing the example of the anti-insurgency campaign in Anbar and Nineva provinces in Iraq, notes that innovation took place without the intervention of military organisations (Russell 2011: 623). Military innovation in this case was warming via the experience of the units on the battlefield. Such innovations begin with "tactical, ad hoc adaptation of troops, while commanders respond to current circumstances and use different combat techniques and equipment on the battlefield" (Russell 2011: 629). According to Farrell, when bottom-up adaptation brings about structural and doctrinal change, it becomes a military innovation. Nevertheless, "the main debates in the academic literature are based on top-down models of military innovation” (Russell 2011: 569-570).

It can be argued that theories explaining military innovations provide a basis for applying the theory of neoclassical realism to the interpretation of military power by defining: a) how changes in the use of military power resources are taking place, and b) whose content of the perception of the security environment influences the change of military power. On the one hand, according to the theory of the force employment, military doctrines are the key element of military power, and military innovation is a means of changing the structure of military power via military doctrines. On the other hand, the power balance model allows the relationship between the systemic level and government variables to be revealed (Lobe 2015: 10-11) - perception of the security environment is an important factor in changing the way military power resources are used. States facing the same threats differ in their ability to extract and mobilise resources: perception of the security environment also influences whether states choose innovation, emulation, or continuity of their existing military strategies (Dyson 2010: 4). Decision-makers have a high level of autonomy in converting threats from the international security environment to changes in military doctrines (Farrell, Terriff 2002: 16). Such theoretical assumptions are consistent with the idea of neoclassical realism providing that no direct link exists between the security environment and foreign policy, and in this case - military power; the connection is created through a filter - the 
content of the perception of the existing security environment. In order to expose changes in military power as an outcome of military innovation, the perception of the security environment of both the military and the political elites is to influence changes in military power (see Fig. 4).

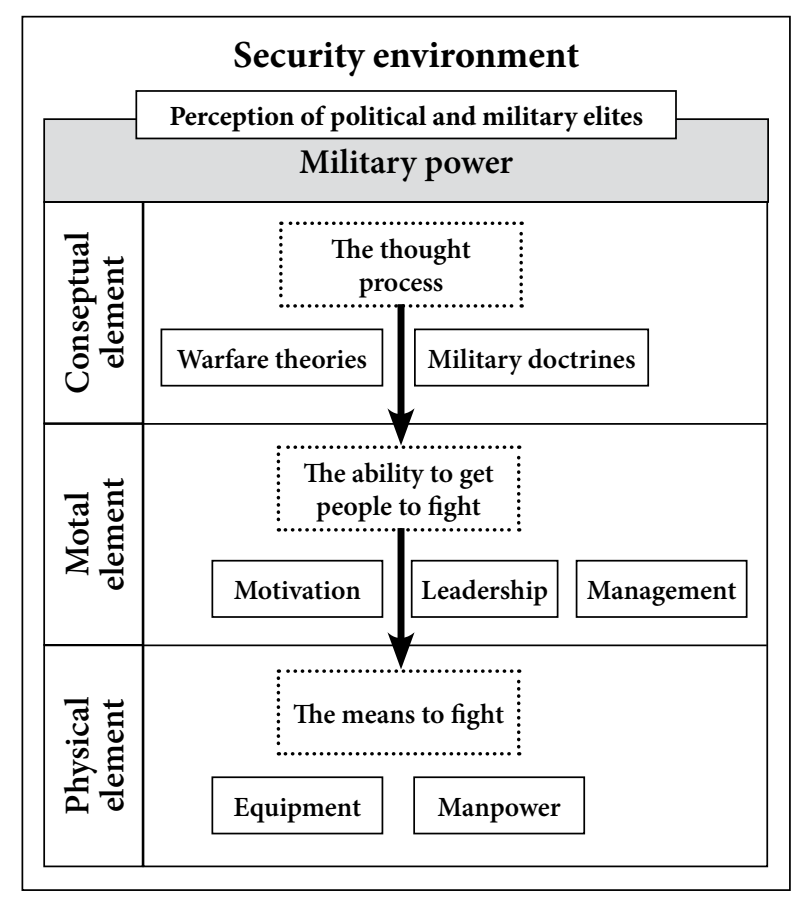

Figure 4. Theoretical model of the interaction between the security environment and military power

Source: created by the author.

The theoretical model of interaction supports the main ideas of neoclassical realism that the transmission mechanism between systemic level and domestic policy decisions is not direct, their interconnectedness depends on the perception of the intervening variable - the security environment. In the light of the theories that explain the military innovations under analysis, groups of actors whose content of the perception of security environment is influenced by the formation of military doctrines, are expanded. The filter of the perception of the political environment of the political elite as an intervening variable is escalated to include the content of the perception of the military elite. This broadening of the content of perception is based on a combination of Posen's balance of power and Rosen's organisational theories in interpreting the causes for military innovation.

Combining the analysis of the content of the political and military elite's perception of the security environment provides a background for revealing in detail the interaction between the security environment and military power: the impact of the security and environment of military operations is not direct and depends on the perception of the military and political elites - by changing the concepts of warfare and the force employment, they are introducing military innovations that are reflected in military doctrines. Military doctrines are a means of changing the structure of military power. Thus, it can be maintained that military power, i.e. tangible and intangible resources and the ways of their use, which ensure the capacity of the army to carry out military acts, assigned tasks, functions and engagements in order to achieve national military goals. Material resources include the physical element of military power, which includes human resources and equipment. Intangible resources are an intellectual/conceptual element that includes military doctrines and war theories, and a moral element that includes motivation, leadership and management. The ways in which resources are used reflect the perception of the security environment of the military and political elite via military innovation. Thus, military doctrines are a tool for changing the way military power is used, adapting military power to the existing security environment. 


\section{Conclusions}

The interpretation of military power on the basis of the material resources base is limited in defining the structure of military power. When defining military power in terms of resources, it is appropriate to maintain the theoretical assumptions that the transformation of resources into desired outcomes depends upon the perception of the security environment. This approach to interpreting military power draws attention to the fact that power as a resource perspective is developed in the works of some representatives of classical realism and, in particular, neorealism who treat exclusively material resources to power, such as military spending, the size of armed forces, gross domestic product, territory and population as a cornerstone of the state power (Ambrosetti 2017: 5-6), is limited in defining the structure of resources comprising the military power ${ }^{3}$. Such conclusions are presupposed by the analysis of the literature of military studies.

The analysis of the literature of military studies has revealed that the intangible resources of military power moral, intellectual/conceptual elements - are an integral part of military power (Fuller 2012: 174). The literature on military studies not only highlights the importance of intangible resources for military power, but also places the greatest emphasis on the intellectual/conceptual element (evolution of military thought) in the structure of military power (See Lithuanian Military Doctrine 2016: 3-3 - 3-4; Land Operations 2017: 3-1). Considering the assessment of the importance of intangible resources in the structure of military power and systemic factors such as security and the environment of international operations in the literature of military studies, it can be assumed that the interpretation of power based on the material resources base does not disclose the complexity of military power in the fundamental interpretation of the structure of the resources constituting military power.

The two theories of international relations used in this article, reflecting the perspectives of combining tangible and intangible resources in defining the structure of military power, have revealed the complexity of military power. Biddle's theory of the force employment not only includes an element of the force employment in the interpretation of military power, but also gives this element of military power the utmost importance in the structure of military power (Biddle 2006: 2-3). The inclusion of the force employment element in the interpretation of military power makes it possible to reveal the change in the structure of military power via military doctrines and tactics. Representatives of neoclassical realism include in their power calculations material resources such as gross domestic product, defence spending, size and composition of the armed forces, size of the territory, etc., and do not distance themselves from the inclusion of intangible resources such as national morale, leadership, quality of diplomacy, etc., in the definition of power (Lobell 2009: 44). Representatives of neoclassical realism emphasise that material resources can determine the behaviour of states, but the influence of these resources can be indirect and complex due to intervening unit-level variables (Berenskoetter, Williams 2007: 58). Thus, the differentiation of military power resources creates conditions for revealing the complexity of military power.

The resources that make up military power are variable. It can be said that the structure of military power is constantly changing - the structure of military power is inseparable from the perception of the security environment and, accordingly, the inclusion of new resources in the structure of military power. This article not only highlights the issue of the change in military power resources, but also gives rise to doubts about the intention of scientists to compile unchanging lists of military power resources (See Raitasalo 2005: 45-47; Mearsheimer 1983: 172; Wohlforth 1993: 7). It is appropriate to discuss not only how much and what tangible and intangible resources should be included in the structure of military power, but also to differentiate the structure of military power based on the context in which military power is used. For example, by differentiating between high, medium, and low intensity conflicts.

Direct military action in the context of modern military conflicts comprise a relatively small part of the army's activities (See Yarger 2015), therefore, with the increasing number of asymmetric, low-intensity conflicts,

It is necessary to pay attention to the fact that a part of representatives of classical realism and neorealism also single out nonmaterial resources while defining state power, for example, Morgenthau includes psychological relation in the definition of power, Waltz - political state stability and political competences (Raitasalo 2015, 45-47). 
mainly caused by nationalist, ethnic, religious and cultural factors (See Herfried 2007; Kaldor 2005, Munkler 2005), changes in the structure of military power become inseparable from who, when and against whom military power is used. In other words, the content of the military elite's perception of the security environment, institutionalised in military doctrines, becomes a means of differentiating the structure of military power by adapting military power to the existing environment of security and military operations.

These research findings complement the Biddle's theory of the force employment applied in the work. The theory of the force employment emphasises the importance of military doctrines and tactics in the structure of military power, but does not indicate in detail how the force employment changes the structure of military power. This article, using the theory of neoclassical realism, details this process by incorporating an intervening variable - the content of the perception of the military and political elite, and by establishing that the use of intervening variables allows the disclosure of changes in the structure of military power.

The influence of the systemic level on the structure of military power is revealed by the unit-level variables. According to the findings of the research, the security environment affects the change in the structure of military power, but this interaction is not direct. The interaction between the security environment and military power is enabled by the intervening variable - the content of the military and political elite's perception of the security environment. Therefore, the security environment affects the structure of military power only when changes in the security environment are perceived as necessary changes in military doctrines and, consequently, in the structure of military power. Indirect influence of the security environment on the structure of military power suggests that military power cannot be interpreted by defining military power resources but without taking into account the intervening variables. This encourages the distancing from the interpretation of military power exclusively at the systemic level, and such distancing inevitably calls into question the expediency of applying theories of international relations focused on the interpretation of the systemic level to the analysis of military power.

The scientific interpretation and study of the structure of military power requires a synthesis of neoclassical realism and theoretical insights into military studies. In this article, the theory of neoclassical realism was chosen for the interpretation of military power due to a two-fold approach to the analysis of foreign policy decision-making (Lindemann 2014: 39), by adapting this approach to the analysis of military power: analysing the influence of both systemic factors (security environment) and internal variables of the state (perception of security policy makers) on the structure of military power. The application of neoclassical realism theory, using the intervening variable - perception of the security environment, reveals how the perception of the security environment changes the structure of military power, thus the theory of neoclassical realism provides more explanatory power in the analysis of military power. Nevertheless, the theory of neoclassical realism can be used for the analysis of military power, given the possibilities and limitations of in the application of the theory.

On the one hand, the advantage of neoclassical realism is that this theory creates assumptions for not to be limited to the analysis of material resources as the sole indicator of military power. Inclusion of intangible resources in the interpretation of military power provides an opportunity to reveal and define the content of military power; interpretation of power based on material resources, in the attempt to apply it to the analysis of military power, does not reveal the complexity of military power and the characteristics and nature of all its constituent resources. Moreover, the prospect of incorporating intangible resources into the structure of military power allows for the comparison of perspectives on the interpretation of military power in academic and military contexts.

And again, the inclusion of unit-level variables in the interpretation of neoclassical realism allows for a more detailed disclosure of the process of extracting resources and converting resources into actual military power. Thus, the theory allows to reveal the process of conversion of military power, but neoclassical realism can be applied to a limited extent in defining the content of military power. ${ }^{4}$ In order to further reveal the changes in

\footnotetext{
$4 \quad$ It should be pointed out that force employment theory argued by Stephen Biddle, a representative of defence-offence balance based on force employment, partially enables the disclosure of the content of military power.
} 
the structure of military power (to define the intervening variables) and the content of military power, the perspective of military studies must be used. The variable of perception of the security environment emphasised in the theory of neoclassical realism includes exclusively the content of the perception of the political elite, and theories explaining military innovations makes it possible to define more precisely how the perception of the security environment influences the change of military power.

\section{References}

Adamsky, D. (2010). The Culture of Military Innovation: The Impact of Cultural Factors on the Revolution in Military Affairs in Russia, the US, and Israel, Stanford, Calif.: Stanford University Press

Allied Joint Doctrine for Land Operations (2016). NATO Standard AJP-3.2, Edition A, Version 1

Allison, G., Zelikow, P. (1999), Essence of Decision: Explaining the Cuban Missile Crisis, 2nd edition, New York: Longman

Ambrosetti, E. T. (2017). "Building a Sphere of Influence in Their Neighbourhood. The Soft Power of Turkey and Russia," PRIMO, No. 5, January, 1-19

Ardant du Picq, C. J. J. J. (1987). Battle Studies in Roots of Strategy, book 2, Stackpole Books

Arreguin-Toft, I. (2005). How the Weak Win Wars: A Theory of Asymmetric Conflict, Cambridge University Press

Baldwin, D. A. (1989). Paradoxes of Power, New York: Blackwell

Barry, B. (eds.) (1976). Power and Political Theory: Some European Perspectives, London: Wiley

Benedict, R. (1946). The Chrysanthenum and the Sword: Patterns of Japanese Culture, Boston: Houghton Mifflin

Bennett, D. S., Stam, A. C. (1996). “The Duration of Interstate Wars, 1816-1985,” American Political Science Review 90, No. 2, June, 239-57

Bennett, S. D., Stam, A. C. (1998). "The Declining Advantages of Democracy: A Combined Model of War Outcomes and Duration," Journal of Conflict Resolution, Vol. 42, No. 3, 344-366

Berenskoetter, F., Williams M. J. (eds.) (2007). Power in World Politics, Routledge

Biddle, S. (2006). Military Power: Explaining Victory and Defeat in Modern Battle, Princenton: Princeton University Press

Biddle, S., Long, S. (2004). "Democracy and Military Effectiveness: A Deeper Look," Journal of Conflict Resolution, Vol. 48, No. 4, August, 525-546

Biddle, S., Zirkle, R. (2008). “Technology, Civil-Military Relations, and Warfare in the Developing World,” Journal of Strategic Studies, Vol. 19, No. 2, 171-212

Boslego, D. V. (1996). The Relationship of Information to the Relative Combat Power Model in Force XXI Engagements, Forth Leavenworth, Kansas

Brooks, R. A., Stanley, E. A. (2007). Creating Military Power: The Sources of Military Effectiveness, Stanford: Stanford University Press

Canadian Military Doctrine (2009). Canadian Forces Joint Publication, Issued on authority of the Chief of the Defence Staff

Castillo, J. (2001). “The Will to Fight: Explaining a Nation's Determination in War,” paper prepared for annual conference of the International Studies Association, February 21

Chacho, T. M. (2001). "Why Did They Fight? American Airborne Units in the Second World War," presented at annual meeting of the American Political Science Association, San Francisco, August 30-September 2

Clausewitz, C. (1993). On War, New York: Alfred A. Knopf

Cohen, E. A. (2004). "Change and Transformation in Military Affairs,” Journal of Strategic Studies, Vol. 27, No. 3, September, 395-407

Cohen, E. A. (2005). “Stephen Biddle on Military Power,” The Journal of Strategic Studies, Vol. 28, No. 3, June, 413-424 
Cordesman, A. H. (2002). Iraqi War Fighting Capabilities: A Dynamic Net Assessment, Center for Strategic and International Studies,

Cote, O. R. (1996). The Politics of Innovative Military Doctrine: The US Navy and Fleet Balistic Missiles, doctoral dissertation, Massachusetts Institute of Technology

Cox, D. G. (2011). "Human Terrain Systems and the Moral Prosecution of Warfare,” Parameters, Vol. 41, No. 3, Autumn, 19-31

Dahl, R. A. (1957). “The Concept of Power,” Behavioral Science, Vol. 2, $201 \square 215$

Davis, V. (1967). The Politics of Innovation: Patterns in Navy Cases, Denver: University of Denver

Decker, J. M. (2015). Enhancing the Effectiveness of Private Military Contractors, doctoral dissertation, Bond University

Desch, M. C. (2002). "Democracy and Victory - Why Regime Type Hardly Matters,” International Security, Vol. 27, No. 2

Desch, M. C. (2008). Power and Military Effectiveness: The Fallacy of Democratic Triumphalism, The Johns Hopkins University Press Doctrine of the armed forces of the Slovak Republic (2003). The General Staff of the Armed Forces of the Slovak Republic, Bratislava Dorman, A. et al. (2002). The Changing Face of Military Power. Joint Warfare in an Expeditionary Era, Palgrave Macmillan UK Duffield, J. (1995). Power Rules - The Evolution of NATO's Conventional Force Posture, Stanford: Stanford University Press Dupuy, T. N. (1985). Numbers, Predictions, and War, Fairfax, Virginia: Hero Books

Dyson, T. (2010). Neoclassical Realism and Defence Reform in Post-Cold War Europe, Palgrave Macmillan UK

Farrel, T. et al. (2013). Transforming Military Power since the Cold War, Cambridge University Press

Farrell T., Terriff T. (eds.) (2002). The Sources of Military Change: Culture Politics and Technology, Boulder: Lynne Rienner Publishers Farrell, T. G. (1996). "Figuring Out Fighting Organizations: The New Organizational Analysis in Strategic Studies," Journal of Strategic Studies, Vol. 19, No. 1, Spring, 122-135

Farrell, T. G. (2010). "Improving in War: Military Adaptation and the British in Helmand Province, Afghanistan,” 2006-2009,” Journal of Strategic Studies, Vol. 33, No. 4, 567-594

Freedman, L. (2005). “A theory of battle or a theory of war,” The Journal of Strategic Studies, Vol. 28, No. 3, June, 425-435

Fuller, J. F. C., The Foundation of the Science of War, Military Bookshop, 2012. Reprint of book originally published in 1926.

Gallo, A. A. (2018). Understanding Military Doctrinal Change During Peacetime, doctoral dissertation, Columbia University

Garnett, J. (1987). “The Role of Military Power,” in Baylis J. et al., Contemporary Strategy I: Theories and Concepts, London: Croom Helm

Gaub, F. (2010). Military Integration after Civil Wars: Multiethnic Armies, Identity and Post-Conflict Reconstruction, Routledge

Gentry, A. J. (2011). How Wars Are Won and Lost: Vulnerability and Military Power, Praeger Security International

Glaser, C., Kaufmann, C. (1998). "What is the Offense-Defense Balance and Can We Measure it?," International Security, Vol. 22, No. 4, 44-82

Global Firepower Index, MilitaryFactory.com Network, https://www.globalfirepower.com, [2018-10-29].

Global Militarization Index, Bonn International Centre for Conversion, https://gmi.bicc.de, [2018-10-29].

Goldman E. O., Eliason L. S. (eds.) (2003). The Diffusion of Military Technology and Ideas, Stanford: Stanford University Press

Goldman, E. O., Eliason, L. C. (2003). The Diffusion of Military Technology and Ideas, Stanford: Stanford University Press

Goldman, E. O., Leslie, C. E. (eds.) (2003). Diffusion of Military Technologies and Ideas, The Stanford: Standford University Press

Gordon, M., Trainor B. (1995). The Generals' War, Boston: Little, Brown 
Gow, J., (2006). "The New Clausewitz? War, Force, Art and Utility-Rupert Smith on 21st Century Strategy, Operations and Tactics in a Comprehensive Context," The Journal of Strategic Studies, Vol. 29, No. 6, December

Grauer, R., Horowitz, M. C. (2012). "What Determines Military Victory? Testing the Modern System,” Security Studies, Vol. 21, No. 1, 83-112

Gray, C. S. (2013). Perspectives on Strategy, Oxford University Press

Grissom, A. (2006). “The Future of Military Innovation Studies,” Journal of Strategic Studies, Vol. 29, No. 5, 905-934

Hayes, B. C., Smith, D. V. (1994). The Politics of Naval Innovation, Research Report 4-94, Newport: U.S. Naval War College

Henderson, W. D. (1985). Cohesion: The Human Element in Combat, Washington: National Defense University Press

Herfried, M. (2005). "What is Really New About the New Wars? A Reply to the Critics," in Olsen J.A. (eds.) On New Wars, Oslo: Norwegian Institute for Defence Studies, 2007

Hinge, A. (2000). Australian Defence Preparedness: Principles, Problems and Prospects: Introducing Repertoire of Missions (ROMINS) a Practical Path to Australian Defence Preparedness, Canberra: Australian Defence Studies Centre

Hironaka, A. (2017). Tokens of Power: Rethinking War, Cambridge University Press

Horowitz, M. C. (2010). The Diffusion of Military Power: Causes and Consequences for International Politics, Princeton: Princeton University Press

Huntington, S. P. (1961). "Interservice Competition and the Political Roles of the Armed Services," The American Political Science Review, Vol. 55, No. 1, March, 40-52

Jakniūnaitè, D. (2011). "Tragiška politikos vizija pagal Hansą Morgenthau,” in Morgenthau H. J., Politika tarp valstybių: kova dèl galios ir taikos, Vilnius: Margi raštai

Jäppinen, M. et al. (2010). "War fighting capabilities and military-technology interaction," The International Society of International Sciences

Jordan, J. (2017). “An Explicative Model of the Processes of Change in Military Organizations: the Response of the United States After 9/11 as a Case Study," Revista de ciencia política (Santiago), Vol. 37, No. 1, 203-226

Ka Po, Ng (2004). Interpreting China's Military Power: Doctrine Makes Readiness, Cass Military Studies, Routledge

Kaldor, M. (2005). New and Old Wars: Organized Violence in a Global Era, DehraDun: Natraj

Kellett, A. (1982). Combat Motivation. The Behavior of Soldiers in Battle, Boston-The Hague-London: Kluwer Nijhoff

Kier, E. (1997). Imagining War: French and British Military Doctrine between the Wars, Princeton: Princeton UP

Kümmel, G. (1999). Morale in the Armed Forces. A Holistic Approach and a Multi-Dimensional Model, Sowi-Arbeitspapier, No. 121

Land Operations (2017), Land Warfare Development Centre, Army Doctrine Publication AC 71940. Wiltshire: Warfare Branch Editor, HQ Field Army

Layne, C. (2006). The Peace of Illusion: American Grand Strategy from 1940 to the Present, Ithaca, New York: Cornell University Press

Lindemann, B. A. (2014). Cross-Strait Relations and International Organizations, Jahrhundert: Springer VS, Wiesbaden

Lithuanian Military Doctrine, D-LK-1 (2016). Second edition, approved by the Commander of the Lithuanian Armed Forces on 22 April 2016, order No V-570, Military Cartography Centre of the Lithuanian Armed Forces

Little, R. W. (1964). "Buddy Relations and Combat Performance," in Janowitz M. (eds.) The New Military: Changing Patterns of Organization, New York: Russell Sage Foundation 195-223

Lobe, N. (2015). Reacting Against Non-Traditional Threats after the Balkan Wars, University of Amsterdam, doctoral dissertation

Lobell, S. E. et al. (eds.) (2009). Neoclassical Realism, the State, and Foreign PolicyCambridge University Press

Lyall, J., Wilson, I. (2009). "Rage Against the Machines: Explaining Outcomes in Counterinsurgency Wars,” International Organiza- 
JOURNAL OF SECURITY AND SUSTAINABILITY ISSUES

ISSN 2029-7017 print/ISSN 2029-7025 online

tion, 63, No. 1, Winter, 67-106

Machiavelli, N. (1994). The Prince, New York: Barnes \& Noble

Mäder, M. (2004). In Pursuit of Conceptual Excellence: the Evolution of British Military-Strategic Doctrine in the post-Cold War Era, 1989-2002, Peter Lang AG

Marshall, S. L. A. (1978). Men Against Fire, Gloucester, Mass: Peter Smith

McGuffie, T. G. (1964). Rank and File. The Common Soldier at Peace and War, 1642-1914, London: Hutchinson \& Co

McMurry, R. (1989). Two Great Rebel Armies, Chapel Hill, University of North Carolina Press

Mearsheimer, J. J. (1983). Conventional Deterrence, Ithaca, New York: Cornell University Press

Mearsheimer, J. J. (2001). The Tragedy of Great Power Politics, New York: W.W. Norton and Company

Morgenthau, J. H. (1967). Politics Among Nations: The Struggle for Power and Peace, 4rd edition New York: Knopf, New York

Moskos, C. C. (1970). The American Enlisted Man. The Rank and Rile in Today's Military, New York: Russell Sage Foundation

Munkler H. (2005). The new wars, Cambridge: Polity Press

Murray, W. R. (2002). Two Lectures: Transformation and Innovation: The Lessons of the 1920s and 1930s Looking at Two Distinct Periods of Military Innovation: 1872-1914 and 1920-1939, Alexandria: Institute for Defense Analyzes

Nagel, J. H. (1975). The Descriptive Analysis of Power, New Haven: Yale University Press

Netherlands Defence Doctrine (2013). Ministry of Defence, The Hague Netherlands Ministry of Defence

Newell, C. R. (1991). Framework of Operational War, Routledge

Nye, J. S. Jr. (2011). The Future of Power, New York: Public Affairs

O’Hanlon, M. (2019). The Senkaku Paradox: Risking Great Power War Over Small Stakes, Washington: Brookings Institution Press

Olsen, J.A. (eds.) (2007). On New Wars, Oslo: Norwegian Institute for Defence Studies

Oppenheim, F. E. (1981). Political Concepts: A Reconstruction, Chicago: University of Chicago Press

Organski, A. F. K., Kugler, J. (1980). The War Ledger, Chicago: University of Chicago Press

Pollack, K. M. (1996). “The Influence of Arab Culture on Arab Military Effectiveness,” doctoral dissertation, Massachusetts Institute of Technology

Porter, P. (2007). “Good Anthropology, Bad History: The Cultural Turn in Studying War,” Parameters, Vol. 37, No. 2, Summer, 45-58

Posen, B. R. (1984). The Sources of Military Doctrine: France, Britain, and Germany Between the World Wars, Ithaca, New York: Cornell University Press

Posen, B. R. (1993). "Nationalism, the Mass Army, and Military Power,” International Security, Vol. 18, No. 2, Fall, 80-124

Posen, B. R. (2016). "Foreword: Military Doctrine and the Management of Uncertainty," Journal of Strategic Studies, Vol. 39, No. 2, 159-73

Raitasalo, J. (2005). Constructing war and military power after the Cold War: the role of the United States in the shared Western understandings of war and military power in the post-Cold War era, Finnish National Defence University, Department of Strategic and Defence Studies, Series 1, No. 21, Helsinki: National Defence University

Reiter, D., Stam, A. C. (2002). Democracies at War, Princeton: Princeton University Press

Richardson, W. R. (1986). "FM 100-5: The AirLand Battle in 1986,” Military Review, Vol. 66, No. 3, 4-11

Rosa, P. (2018). Neoclassical Realism and the Underdevelopment of China's Nuclear Doctrine, Palgrave: Pivot 
Rosen, S. P. (1991). Winning the Next War: Innovation and the Modern Military, Ithaca, New York: Cornell University Press

Rosen, S. P. (1996). Societies and Military Power: India and Its Armie, Ithaca, New York: Cornell University Press

Rotte, R., Schmidt, C. M. (2003). "On the Production of Victory: Empirical Determinants of Battlefield Success in Modern War," Defence and Peace Economics, Vol. 14, No. 3, June

Ruffa, C. (2008). Imagining War and Keeping Peace? European Military Cultures in a non ESDP Peacekeeping Operation: the case of UNIFIL, European University Institute, Paper to be presented at the ECPR Joint Workshop Session, Rennes, April

Russell, J. A. (2011). Innovation, Transformation, and War: Counterinsurgency Operations in Anbar and Ninewa, Iraq, 2005-2007, Stanford: Stanford University Press, 595-624

Sapolsky, H. M. (1972). The Polaris System Development: Bureaucratic and Programmatic Success in Government, Cambridge: Harvard University Press

Sapolsky, H. M. (2000). “On the Theory of Military Innovation,” Breakthroughs 9, No. 1, 35-39

Schmidt, B. (2005). “Competing Realist Conceptions of Power,” Millennium: Journal of International Studies, Vol. 33, No. 3, 532-33

Schmidt, B. C. (2007). "Realism and Facets of Power in International Relations," in Berenskoetter F., Williams M. J. (eds.) Power in World Politics, Routledge, 43-63

Segal, D. R., Sinaiko, W. H. (1987). Life in the Rank and File. Enlisted Men and Women in the Armed Forces of the United States, Australia, Canada and the United Kingdom, Washington: Pergamon-Brassey

Shils, E. A., Janowitz, M. (1948). "Cohesion and Disintegration in the Wehrmacht in World War II," Public Opinion Quarterly 12, Summer, 280-315

Shimshoni, J. (1990/1992). “Technology, Military Advantage, and World War I: A Case for Military Entrepreneurship,” International Security, Vol. 15, No. 3, Winter

Singer, D. J. (1972). The Wages of War, 1816-1965: A Statistical Handbook, Wiley

Singer, D. J. (1982). Resort to Arms: International and Civil Wars, 1816-1980, SAGE Publications, http://www.correlatesofwar.org, [2018-10-29]

Singer, D. J. (1988). "Reconstructing the Correlates of War Dataset on Material Capabilities of States, 1816-1985," International Interactions, Vol. 14, 115-32

SIPRI Military Expenditure Database, Stockholm International Peace Research Institute, https://www.sipri.org/databases/milex, [2018-10-29].

Sloan, G. (2012). "Military doctrine, command philosophy and the generation of fighting power: genesis and theory," International Affairs, Vol. 88, No. 2, March, 243-63

Slovenia Military Doctrine (2006). Doctrine, Development, Education and Training Command, Government of the Republic of Slovenia Snyder, J. L. (1984). The Ideology of the Offensive: Military Decision Making and the Disasters of 1914, Ithaca, New York: Cornell University Press

Stam, A. C. (1996). Win, Lose, or Draw: Domestic Politics and the Crucible of War, Ann Arbor: University of Michigan Press

Sullivan, P. L. (2007). "War Aims and War Outcomes: Why Powerful States Lose Limited Wars," The Journal of Conflict Resolution, Vol. 51, No. 3, 496-524

Sun Tzu (1971), transl. Samuel B. Griffith. The Art of War, London: Oxford University Press

Tedeschi, J. T., Bonoma, T. V. (1972). "Power and Influence: An Introduction,” in Tedeschi J. T. (eds.), The Social Influence Processes, Chicago: Aldine $\square$ Atherton, $1 \square 49$.

UK Defence Doctrine (2014). Joint Doctrine Publication 0-01 (JDP 0-01), Ministry of Defence, Development, Concepts and Doctrine Centre, 5 th edition, November

Vicent, D. (1967). The Politics of Innovation: Patterns in Navy Cases, Denver: University of Denver 
JOURNAL OF SECURITY AND SUSTAINABILITY ISSUES

ISSN 2029-7017 print/ISSN 2029-7025 online

Waltz, K. N. (1979). Theory of International Politics, New York: Random House

Wilson, J. Q. (1989). Bureaucracy: What Government Agencies Do and Why They Do It, New York: Basic Books

Wohlforth, W. C. (1993). The Elusive Balance: Power and Perceptions During the Cold War, Cornell Studies in Security Affairs, Cornell University Press

Woodward B. (1991). The Commanders, New York: Simon \& Schuster

Yarger H. R., (eds.) (2015). Short of General War: Perspectives on the Use of Military Power in the $21^{\text {st }}$ Century, Strategic Studies Institute, Department of The Army

Zisk, K. M. (1993). Engaging the Enemy: Organization Theory and Soviet Military Innovation, 1955-1991, Princeton: Princeton University Press

Agniete ZOTKEVICIUTE BANEVICIENE is a lecturer at the General Jonas Zemaitis military academy of Lithuania and have a PhD in political science. Research interests: military power, cultural awareness, terrorism.

ORCID ID: orcid.org/0000-0003-1232-7257

Register for an ORCID ID:

https://orcid.org/register

This work is licensed under the Creative Commons Attribution International License (CC BY) http://creativecommons.org/licenses/by/4.0/ 